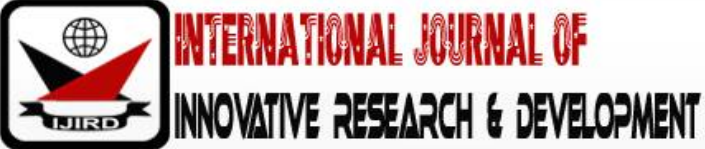

ISSN 2278 - 0211 (Online)

\section{Women, Politics, Language Shift and Maintenance in Kenya: Case of Lullogoli in Diglossic Uriri Sub-County, Kenya}

Nabeta KN Sangili
Tutorial Fellow, Kaimosi Friends University College, Kenya
Sangai Ernest Mohochi
Academic Registrar, Kibabii University, Kenya
Dr. Nyandiba Carren
Senior Lecturer, Rongo University, Kenya

\begin{abstract}
:
Kenya is a typical African multilingual state with well over 43 languages. All these languages are spread across the 47 counties. Migori County, one of the 47, is a dynamic potpourri of multilingual county: Cushitic, Nilotic and Bantu. These language families have found themselves in contact for close to eight decades due to interceding factors like politics, exogamy marriages, education, work, migration and search for land, resulting in language maintenance and shift. Of pronounced concern to our debate, here is women and politics in maintenance and shift of Lullogoli. Women have been known, since time immemorial, to be agents of language change, shift and maintenance. This can also be said about politics. Politics (positive and negative) have led to maintenance and shift of indigenous languages in various countries, including Kenya. These factors are under investigation in our current study. We aim to find out their role in shift and maintenance of Lullogoli in Migori County. We seek answers for the following questions: what is the role of women in maintenance and shift of Lullogoli; how has local and national politics contributed to maintenance and shift of Lullogoli?
\end{abstract}

Keywords: Shift, maintenance, Lullogoli, women, politics

\section{Introduction}

Language maintenance has been defined variously: a situation in which a speaker, a group of speakers, or a speech community continue to use their language in some or all spheres of life despite the pressure from the dominant or majority language" (Pauwels, 2004, p. 719);language maintenance is the degree to which an individual or group continues to use their language, particularly in a bilingual or multilingual area or among immigrant groups (Longman Dictionary of Language Teaching and Applied Linguistics, 2002). Habtoo (2012) avers with Pauwels when he says that language maintenance refers to the situation where speech community continues to use its traditional language in the face of a host of conditions that might foster a shift to another language. Batibo (2005: 102) argues that language maintenance implies, therefore, that the degree of resistance is strong enough to contain any pressure that may be coming from a dominant language. The domains of L1 remain largely the same and transmission of the language to the children is active and as perfect as possible. Moreover, the number of speakers remains relatively stable, maintaining a strong allegiance to their language. This can happen in monolingual or stable diglossic situations. When maintenance efforts are weakened or abandoned at some stage, then we no longer talk of maintenance but shift.

Language shift signifies the phenomenon, which can be observed in unstable bi- or multilingual situations in which one community gradually changes 'from the habitual use of one language to that of another' (Weinreich, 1953: 68). Language shift pivots itself on the weakened efforts of language maintenance. However, in as much as shift focuses on community, it should be noted that within one language community, there can be two groups pulling in two different directions: maintenance and shift. We shall review the possibility of this phenomenon later in our analysis. All these definitions point to one simple conclusion that, regardless of linguistic situation, language maintenance and shift is a deliberate effort to secure the use of a language.

Language shift and maintenance in Kenya is not a new phenomenon, though Kenyan scholars have not taken it with deep interest if we were to compare, for instance, with the Western scholars. However, available literature on Kenya's contact linguistics situation needs to be evaluated and shored up in this century. Existing researches on language contact in Kenya have largely dwelt on endangered languages, language attitudes, language maintenance among university students andlanguage ideologies (Wamalwa and Oluoch, 2013; Orcutt-Gachiri, 2009; Mberia, 2014; Wanjala, 2009; Obiero, 2008; Kipsisey, 2009; Fink, 2002). Available literature shows that in Kenya, few languages have been pointed out as dying, while some have already disappeared from the linguistic map(Ethnologue, $16^{\text {th }}$ edition). Language death occurred because the indigenous speakers did not see the need for maintaining them and hence, they shifted to other stronger and imperializing languages. Some linguistic minority communities, having realized the value of their languages, began efforts 
to revitalize them and currently are maintaining them. For instance, in the early 1990s, Suba, a Bantu language, was on the verge of disappearance after the speakers migrated from Uganda to Kenya due to cultural reasons (Obiero, 2013). Suba encountered a much stronger and imperializing Nilotic Dholuo language and after the third generation of speakers, there was a massive shift to Dholuo. Dholuo became their L1 while for some, Suba became their L2. We say for some because the younger generation did not know Suba. However, there was an outcry, and for political and lingua cultural reasons, Suba revitalization began. This revitalization is currently ongoing and we now have all generations speaking Suba as their L1 and Dholuo as L2 (Obiero, 2013). However, we have individual persons who, having stayed away from the Suba network due to work, marriage or education related reasons, cannot manage a coherent discourse in Suba, their L1. But they still make regular visits to Suba, their motherland.

The language we have given as an example is found in the linguistic belt we are dealing with: the larger Southern Nyanza of Kenya. This region has more than 7 languages in contact, and of interest to us is the Lullogoli language. Lullogoli is a Bantu language that migrated from the current Vihiga County in the late 1930s, passing through Kisii Hills and later settled in Migori County in 1943/44. It is believed that we even before 1940s, there were Maragolis already living in Migori; they mainly composed of social misfits who were expelled due to incest and other social evils. According to the narrative I collected from interviews, the first group to settle in Migori composed of 60 families that migrated from Bukuga, Mbale, and Chango. Overtime, more families joined the first group. Although the exact number of the Lullogoli speakers is not yet statistically established, the narrative that the researcher received estimates them to be more than 80 , 000 adult speakers. Some old men and women interviewed who are now in their late 80s and 90s claim to have migrated with their parents when they were just little kids of between 10 to 12 years old. Some of them do not have living contacts in their ancestral land and the generations that were left behind no longer recognize them. Migrations were not a one-off activity but throughout the years, Maragolis kept coming to Migori, and some are still migrating up to now. Some came because of work; others came to look for fertile lands to till while others came to reunite with their relatives who had migrated earlier. Migori county was initially inhabited by the Dholuo and Kuria speakers but currently, the language ecology of the region is quite complex.

Lullogoli is a language that has been in contact with Dholuo for quite some time, precisely for more than 80 years. Unlike Suba or other languages with smaller populations, Lullogoli has maintained itself for over 8 decades without showing signs of extensive reduced domain use or substation. Just like the imperial Dholuo, Lullogoli is spoken at home, in the market places, in Maragoli dominated churches, in cultural ceremonies like circumcision, naming, burial, weddings, commemorations, on the roads and in farms. The language is spoken by the elderly, the youth and the children in fluent measure. While conducting my fieldwork, I was amazed to note that even the native Dholuo speakers can converse fluently in Lullogoli just as the Maragolis can speak fluent Dholuo. Geographically, the Maragolis are not scattered as such. Though we have, few homesteads flung everywhere; most of the Maragolis stay together. In a whole sub location for instance, you will find a dozen Dholuo homesteads as compared to tens of Lullogoli speakers. The Dholuo homesteads, which are sandwiched between Lullogoli speakers, had no otherwise but to learn and speak the language. However, it is worth noting that the Dholuo speakers maintain their language despite them learning Lullogoli. They use the two languages interchangeably when the need for code switching or mixing arises. This kind of close social networking has helped maintain Lullogoli.

\section{Linguistic Landscape of Migori County}

Migori county is one of the 47 counties in Kenya with an estimated population of 917,170 as of 2009 Census statistics with 472, 814 (51.4\%) women and 444, 357 (48.6\%) men. It is projected that by 2017, the population would increase to between 1.1-1.2 million people covering 2,596 square kilometers. The county has seven sub counties, 23 divisions, 76 locations (Wards) and 174 sub locations. Our area of study is Uriri Sub County, which has a total of 5 Locations (Wards) and 19 villages. Linguistically, Migori County is a complex ecology. The languages spoken in this region include: Kiswahili, Dholuo, Kuria, Luhya (several dialects), Ekegusii, Somali, Gikuyu, Kamba, among other languages. Kiswahili is rated as number one because it is the National and Official language of Kenya hence almost everybody in this region can speak it. In terms of indigenous language ranking, Dholuo is the first, followed by Kuria, Luhya, Ekegusii and the other languages. As earlier stated, Luhya has several dialects represented in this area. Whenthey are rated by population, Lullogoli is leading (with estimated 80, 000 adult speakers), followed by Bukusu and other minor dialects like Kisa, Nyore, Tsotso, Samia and Tiriki.

Lullogoli, also called Logoli, Maragoli, Maragooli, Uluragooli or Logooli, is one of the Great Lakes Bantu languages spoken in Kenya by over 618, 000 people (Census, 2009)and classified by Guthrie as E.41(Maho, 2009). It is also spoken in Mara Region of neighboring Tanzania (Lewis, Gary and Charles, 2015). According to the elders interviewed by the researcher, the Maragoli speakers in Tanzania migrated from Migori as they sought to explore more land in early 1940s. Their migration history has been explained by two different theories: the European migration theory and the Traditional Oral Narrative Theory. European Migration theory posits that Maragoli, as part of the larger Luhya community migrated from Niger Congo with other Bantus in what is historically known as The Great Bantu Migration. According to their oral narrative, the Lullogoli speakers migrated from Egypt through Southern Sudan and settled for a short time in Northern Kenya at a place called Lokitaung. They later moved further down to their current home in Vihiga County of Western Kenya. Several centuries later, some Maragoli speakers would later disperse from their ancestral home to other parts of Kenya. Currently, we have Maragoli speakers in Counties of Bungoma, Nandi, Homa Bay, Nairobi, Kisii, Kakamega, Trans Nzoia, Uasin Gishu and Migori. These vast regions of Kenya are known to have sizeable population of Maragoli speakers. All these counties have different languages coming in contact with Lullogoli. However, their contact status is yet to be established. 


\section{Theoretical Framework}

Our analysis was based on Giles, Bourhis and Taylor's theory of Ethno linguistic vitality. Giles et al. (1977) argue that when ethno linguistic vitality is approached from a typological perspective, three variables are factored: status, demography and institutional support. Depending on how these three combine, they permit an ethno linguistic minority to survive as a distinct group thus maintaining their identity or disintegrate and shift to superior language. Demographic variable involves several sub-sets of variables like the number of group members and population distribution while status will include economic status, social status, socio-historical status and prestige of the language within and without the cultural territories. Institutional support on the other hand refers to the formal and informal representation of the ethno linguistic minority in various institutions of a nation, region and community. According to Giles et al. (1977), these three variables interact to provide a clear context for understanding language maintenance and shift. They argue that the more vitality a group has, the more it is likely to survive as a compact group, and conversely, the weaker it is, the lesser likely it will survive as a group. These tenets are used in this paper to clearly explain the maintenance and shift of Lullogoli in Migori County, Kenya.

\section{Data Collection}

Collection of data was through participant and non-participant observations and structured interviews from 30 respondents in Uriri Sub-County, Migori County. The researcher narrowed to Bware Sub location due to the linguistic setting of the area. The research was conducted between December 2016-February 2017. The interviews covered the following major areas: a) marriage, women and language use, b) attitude of Maragoli and Luo women towards Lullogoli, c) how local and national politics have affected Lullogoli d) administration and Lullogoli maintenance. The following domains of Lullogoli use were observed: a) homes, b) farms, c) markets/ shopping centers, d) churches, e) roads and f) children playing fields. Most of the interviews were conducted in the homes of participants. The interviews were conducted in Lullogoli because literacy level among the elderly is low and a way of measuring their competence. The major findings are discussed in the next section.

\section{Women, Maintenance and Shift of Lullogoli in Migori}

In an interview with a church elder in Bware Sub location, he confessed that women who are married to Luo men eventually develop an affinity to Dholuo and Kiswahili. Whenever they attend church meetings, they seem to find it hard expressing themselves fluently in Lullogoli. To hide their linguistic shortcomings, they shift to Kiswahili even when all members are Lullogoli speakers. However, he defended this group of women arguing that culturally, a woman, when married in another linguistic community; she is compelled to learn the language of the husband. She has to feel at home and integrated into the new family by learning their language. However, as she learns and regularly uses Dholuo, she begins to be separated from her native linguistic network. Her language, Lullogoli, recedes into disuse and eventual attrition. She begins to forget some technical words, remaining only with basic vocabulary in her mental repository. When she realizes that she is struggling with Lullogoli, she switches to Kiswahili (and/ or sometimes Dholuo) in order to veil her weakened Lullogoli competence. According to Giles et al (1997), such will happen only when an individual or a group breaks away from the concentration zone. The linguistic forces of shift become stronger for such women and eventually they fail to resist. Failure to resist means she has to embrace a stronger Dholuo language. However, this case, it should be noted, mostly applies women married far away from her Lullogoli network. This explained why Maragoli women married in villages like Ombo and Katieno seem to struggle with their native language whenever they visit friends and relatives in Bware and Lwala. Our research showed that these women are gradually shifting to Dholuo, including their children. Their children though they can comprehend few Lullogoli words, they cannot speak it. They resort to Kiswahili or Dholuo to communicate. However, it should be noted that these women and their families are not concentrated with the linguistic network. The case is completely different from that of those women found within the Lullogoli network, specifically Bware, Lwala, Kakrao, Stella, Muhanda among other places.

There are some Maragoli women who are married to Luo men within Bware sub location but have maintained their language and even their children speakLullogoli. Bware sub location is predominantly inhabited by Maragoli speakers. In conversation with some elders, they said that when they migrated to Migori, they were given this area, as it was virgin and uninhabited. So Bware was completely inhabited by Maragoli people. However, later, Luos began to inhabit the sub location after purchasing parcels of land from the Maragoli. These Luo families learnt Lullogoli, their young men married Maragoli women and lived within the sub location. This category of women maintained their language because they did not move away from the concentrated network. They are now considered as repositories of Lullogoli language and culture. In their daily activities, these women interact and work in Lullogoli and lesser, in Dholuo. The area ultimately became a stable isogloss. Milroy (1980) and Blom and Gumperz (1972) suggest that when the network structure is so close-knit, language maintenance becomes easy as the speakers are able to unify and resist linguistic and social pressure that comes from outside group. The closeness of Lullogoli speakers is what has helped them maintain their language by sucking in the Dholuo speakers who came and dwelt among them for over 8 decades. However, many Maragoli speakers could not resist learning Dholuo, maybe on a reciprocity basis.

It is worth noting that we have many Dholuo speaking women married to Maragoli men in this area. Some are now old with grandchildren. In an interview with one woman, now in her late 50s, she confessed that initially she did not know Lullogoli when she got married. She did not find it good manners to bring her strange tongue (her native Dholuo) to a people who already have their tongue (Lullogoli). Therefore, she began learning the language. After some years, she became so perfect that she currently speaks like a native Lullogoli speaker. She also ensured that all her children learnt the language, even though they later came to learn Dholuo from their friends outside their home. When asked which language 
is dominant in the home, she said "of course Lullogoli!" I asked her two grown up daughters who are about 22 and 26 years old, who they would get married to: one said if she gets a Dholuo suitor, well and good, if she gets a Maragoli, even better! Apparently, the elder had gotten married to a Luo man but the marriage had broken. She was hesitant to answer the question. But they all insisted that whichever way their marriage would go, they would maintain their Lullogoli because it gives them an identity. The two daughters speak fluent Dholuo as their L2. Their mother continues to maintain her own tongue through visitations, Luo women group meetings and normal interactions with Luo neighbors dotted within the sub location. Generally, in every society, women, especially mothers, are regarded as repositories of culture and responsible for the maintenance of tradition and language (Kuncha\& Bathula, 2004).

Language attitude of women was also a factor under consideration. The women surveyed and elders interviewed showed a remarkable positive attitude towards maintaining their language. This was also evident in the cultural ceremonies observed like age-set naming ceremony conducted in Kamsaki, Mukuyu Primary School. There were more women than men who attended the ceremony. They were proud of their language and their culture. Figure 1 shows a group of women who had just finished welcoming the newly circumcised boys to the age-set naming ceremony with pomp, dances and Lullogoli cultural songs.

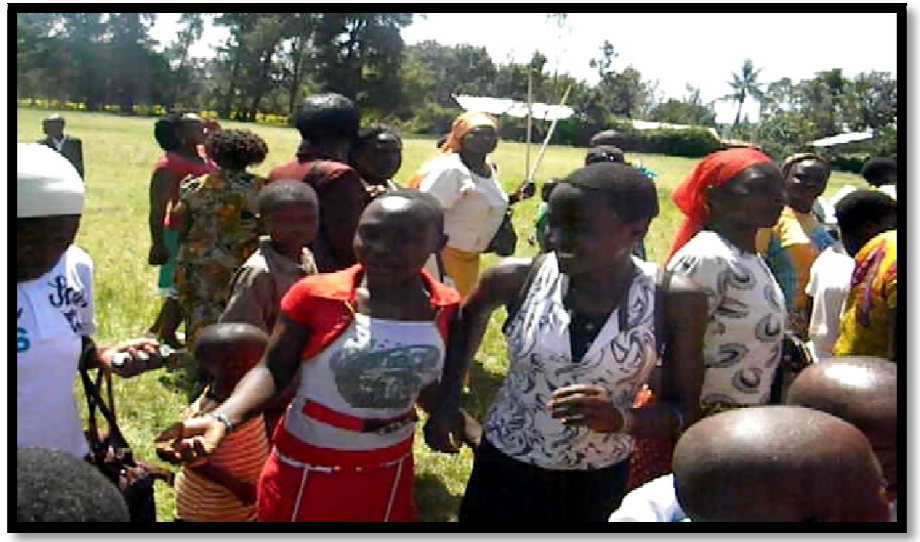

Figure 1: A Group of Maragoli Women Attending the Age Set NamingCeremony, Mukuyu Primary School

This was the case with child baptism ceremony conducted in the home of a Salvation Army church couple where women were dominant than men. They sang and talked in Lullogoli, albeit mixing with Kiswahili language but not in Dholuo. The use of Kiswahili in the ceremony was mainly for the guests who did not have an excellent grasp of Lullogoli. Dholuo speakers (both men and women) do not show negative attitude towards Lullogoli. In fact, it is amazing to note that in my observations, most Luo speakers in Bware sub location understand and can speak Lullogoli. The Dholuo women allow their children to mingle and play with Maragoli counterparts. And as they grow together, they become perfect bilinguals who can speak Dholuo and Lullogoli in equal measure. Positive attitude among Luo women and men was set in early 1940s when the first group of Lullogoli speakers arrived in Migori. The Luo leader, who was also a seer, dreamt that strangers, speaking a tongue unknown to them, were coming to their land (Luo land) and they were good people. He foretold that the Luos and Maragolis would live in peace alongside each other. So, when the Maragolis arrived, they received warm reception. They were never hated or looked down upon. Indeed, in African culture, a stranger who sought refuge and new lease of life among a community was welcomed and given land to occupy and start a new life. But this happened only after a deep interrogation about the reasons for coming to the land of strangers. So, the Maragolis were given a new lease of life in Migori. Several years later, exogamy would be rampant: Luo women would begin getting married to Maragoli men after learning their language and Maragoli women would learn Dholuo and marry into the community. Exogamy became a way of maintaining languages in what would eventually become a stable isoglossic environment. However, some few Maragoli women refused to marry Luo men because their Maragoli culture insisted on male circumcision. Young men had to be brought from their ancestral land, Vihiga while others went to look for husbands from Kuria region. In Bware, all languages are respected, loved, used and advanced in equal measure. Lullogoli is used in predominantly Maragoli churches, markets, shopping centers, in farms, in women groups, on the road, in play fields among other places. The same situation is can be said about Dholuo language.

\section{Politics, Maintenance and Shift of Lullogoli in Migori}

The interrelationship between political space, participation, language maintenance and shift is a complex one. It can be viewed from the narrow prism of political leadership among the linguistic minority to a wider aperture of land ownership, seeking independent political entities like Catalans, Flanders or the Flemish, and campaigning for linguistic inclusion of minority in educational systems. Lullogoli speakers in Migori County, even though they are minority as compared to Dholuo speakers, have decried the underrepresentation in the political systems of County governance. Since 1940s, they have never had a Maragoli Member of Parliament in previous Central system of governance despite the fact that they hold a sizeable voting population within the sub counties. At one time, in the wake of the new millennium, they wanted to curve out a political constituency of their own. As minority community, they felt alienated from political participation and representation of the larger Migori. However, they later backtracked from the process because it was 
perceived as recoiling into tribal cocoon when the nation was moving towards ethnic inclusivity. Seeking administrative autonomy reminds us of one question Connolly (2013) asks in his paper: Why did theFlemish, Scottish, and Catalan nationalists seek separation in the midst of an integrating continent? One of the answers he found out was the language issue. The Catalans and the Flemish felt the need to speak their own language, use it in economy and administration among other things. Therefore, seeking autonomy meant trying to protect their cultural and linguistic identity. Apparently, in the history of Spain, the Catalans had been repressed severally and worse moments for them came during the reigns of Francesco Franco after the Spanish Civil War. In the words of Desquens (2003), Catalans "endured repression of individual and collective cultural rights, such as the prohibition of the use of the Catalan language, the public denial of the Catalan identity and the punishment of cultural expression." We could easily twist the reason and explain why the Lullogoli speakers wanted to curve out a political constituency of their own. They felt alienated from political representation yet they were compelled to participate in every plebiscite. However, it is worth noting that unlike the Catalans, Maragolis and their language have never been publicly repressed by the Luo, Kuriaor other communities within the region. It has been allowed to flourish alongside other indigenous languages.

Nevertheless, in the recent past, Lullogoli speakers have been represented in the local governance system. For a long time, they have had Maragoli chiefs championing their rights, their culture and value systems. Their role has been very important in arbitrating land and minor cases between the Luo and Maragoli. Through these efforts, they have been able to dissipate any tribal pressures that could deteriorate into fights. Whenever fights occur between the majority and minority, the latter will always suffer prejudice. They will also feel unsafe moving around and speaking their language. Eventuality of such fear is reduced domains of minority language use and exacerbated shift in order to feel safe in the hands of the perceived 'enemy'. But this has not been the case with Lullogoli. It has been maintained over these long periods because the social status and prestige is protected by these chiefs. Fundamentally, Maragolis having chiefs means that Lullogoli has received administrative recognition from the Central and Devolved Governments. This is what Giles et al (1977) meant when they said that when an indigenous language is represented formally and informally in various institutions of a nation, region or community, then it is able to survive as a group.

Kenya has had political disquietness in several general elections. The worst election was in 2007 where politics took an ethnic angle, later turning into ethnic cleansing. It is estimated that over 1300 people lost their lives while hundreds of thousands were misplaced because they were 'illegal internal immigrants'. Undercurrent factor that was used to separate one group from the other was linguistic identity. If you were known to speak a language different from the indigenous, you were weeded out, forcefully. Those who learnt and spoke the language of the locals were not spared either. These upheavals were spread across the nation.

While talking to some elders in Bware and Kamsaki sub locations, I sought to know if past elections have affected the social fabric at one time or another. One elder said, yes, the Lullogoli and Ekegusii speakers were not spared. But it only affected those who had bought parcels of land in the predominant Luo spaces. The Luos identified the strangers by the language they spoke, even though the Lullogoli speakers had learnt and were speaking more Dholuo than their native tongue, Lullogoli. They burnt their houses, chased them from their homes and seized their possessions, including lands and houses. However, later, the local leadership, spearheaded by chiefs, village elders and other regional politicians staged several intermediating meetings to resolve the impasse. It is only after the meetings that the Lullogoli speakers returned to their homes. However, some sold their parcels of land and shifted to the areas dominated by Lullogoli speakers like Bware, Kamsaki and Muhanda. While in the field, one story was narrated of a man who lost his siblings due to sicknesses prior to the skirmishes. He had been completely immersed in Dholuo language and culture so much so that he had forgotten his own language, Lullogoli. Apparently, his parents had caused them to shift to Dholuo as early as 1970s. When the skirmishes took place, he decided to sell his land and move to Kamsaki area. He began learning Lullogoli, the language of his parents. This was an ardent and a conscious effort to reverse language shift. Sour politics had caused him to learn, speak and maintain his native language.

The 2013 general elections were relatively peaceful though few Maragolis and Kisiis were threatened because of what was taking place in the national political arena. National politics affected local politics of Migori. Kenyan politics is essentially tribal based rather than issue or ideology based. The 2013 campaigns witnessed some political tectonic plating' when Honorable Musalia Mudavadi, the political Father figure of Maragoli decamped from ODM, a party that was spearheaded by Luo Leader, Prime Minister, Right Honorable Raila Odinga, to Jubilee Party led by Uhuru Kenyatta, the current Kenyan President. The Luos in some parts of Migori saw this political change as betrayal by the Maragolis. Anyhow, the bond that had been forged after the 2007 violence did not allow the threats to take ugly shape.

Canvassing for votes in Migori County and largely Kenya is a delicate issue. It is about impressing an ethnic group if you do not belong to them. It is about learning and using few words of their language if you do not know any. It is about advancing the rights of minority and marginalized groups. All aspirants who have campaigned for votes in various electoral entities of Migori County have encountered Maragoli people. They have had to learn their language, albeit few words that can string a political conversation. While attending a Maragoli political cum cultural rally in Mukuyu primary school in December 28, 2017, I observed that aspiring Kuria and Luo leaders had to speak Lullogoli to impress the Maragoli. They would begin with "Mirembe" (Peace/Shalom) greetings before delving into the issues of the day. One politician, Honorable Achilo Ayako reminded the sitting governor, His Excellency Okoth Obado that if he does not champion the needs of Lullogoli speakers, he risked being voted out. The same was said to and by other local leaders who are vying for 2017 MCA (Member of County Assembly) and Member of National Assembly (MP) seats. Such needs include but not limited to maintaining their cultural ceremonies, language, values and beliefs, jobs, and general social fabric as it has been since 1940s. My interviews with Maragoli elders indicated that they did not want to lose their language and culture. Losing culture means losing a language. That is why Fishman (2001: 21)argues that cultural loss reinforces 
identity change, so that language becomes less important for the peoples and this leads to language shift. But when culture is maintained, then language is also maintained. Such political pressure has led to the Maragolis being voted, nominated and appointed into various county political offices. These appointments have soared the prestige, pride, identity and glory of Maragoli thus giving them an eminent status within the multi-ethnic and multilingual county of Migori. Through these political spaces, they have been able to maintain their language.

\section{Conclusion}

Migori County is fundamentally a stable diglossic situation. This explains why Lullogoli has been able to maintain itself despite the pressure from the dominant and superior Dholuo language. Women, as our study has found out, have been a major factor in determining the maintenance or mild shift of Lullogoli since early 1940s up to date. Except for the few who have been married into Dholuo community and are living far away from the concentrated Maragoli network, many have been able to pass the language to their children and grandchildren.The stable intergenerational transmission of Lullogoli means that maintenance is on course. Women from both communities displayed very positive attitude towards Lullogoli. They are proud of their language; they use it in various expanded domains like homes, farms, churches, and on the road with fellow women or community members. Even though language maintenance has been largely known to be communal or group affair, we have observed that few women with their children have individually shifted to Dholuo due to exogamy.

Apart from women, politics have played a very fundamental role in maintaining Lullogoli. Politics in our discussion took an expanded view where we discussed political participation, land ownership issue, canvassing for votes and general inclusivity. Maragoli speakers have clamored for political representation in the previous central governments and the current devolved units. Their pressure has led to their sons and daughters being voted, nominated and appointed into several public offices. Through these offices, they have been able to champion their cultural rights, values and beliefs, language perpetuation and even sort out amicably land issues that arise due to ethnic bigotry. The peaceful coexistence between these two communities has made both languages thrive and maintain themselves though mild shift was observed.

\section{References}

i. Batibo, H. (2005).Language Decline and Language Death in Africa: Causes, Consequences and Challenges. New York: Multi Lingual Matters Ltd.

ii. Connolly, C. K. (2013). Independence in Europe: Secession, Sovereignty, and the European Union. Copy available at: http:// ssrn.com/ abstract=2231162.

iii. David, M.K. (n.d.). Reasons for language shift in peninsular Malaysia. Journal of modern languages.

iv. Desquens, J. (2003).Europe's Stateless Nations in the Era of Globalization: The Case for Catalonia's Secession from Spain, BOLOGNA CTR. J. INT'L AFF.

v. Fink, T. K. (2002). Attitudes toward languages in Nairobi. BA Thesis. University of Pittsburgh.

vi. Fishman, J. (1991).Reversing Language Shift. Theoretical and Empirical Foundations of Assistance to Threatened Languages. Clevedon: Multilingual Matters.

vii. Giles, H., Bourhis, R. Y. and Taylor, D. M. (1977). Towards a theory of language in ethnic group relations.In language, ethnicity and intergroup relations, ed. H. Giles, 307-345. New York: Academic Press.

viii. Habtoor, H.A. (2012). Language Maintenance and Language Shift among Second Generation Tigrinya-speaking Eritrean Immigrants in Saudi Arabia. Theory and Practice in Language Studies, Vol. 2, No. 5, pp. 945-955, May 2012.

ix. Kipsisey, G. C. (2010). Reviving Marginalized Languages in Kenya: A Case Study of the Sabaot on Mount Elgon.Paper presented at the 109th Annual Meeting of the American Anthropological Association held in New Orleans on Nov. 17-21 2010

x. Kuncha, R. K., \& Bathula, H. (2004). The role of attitudes in language shift and language maintenance in a new immigrant community: A case study. Working Paper No. 1

xi. Lewis, M. P., Gary, F.S. \& Charles, D.F. (eds). (2015). Ethnologue: Languages of the World, Eighteenth edition. Dallas, Texas.

xii. Obiero, O.J. (2008). Evaluating language revitalization in Kenya: the contradictory face and place of the local community factor. Nordic Journal of African Studies 17(4): 247-268.

xiii. Orcutt-Gachiri, H.A. (2009). Kenyan Language Ideologies, Language Endangerment, and Gikuyu (Kikuyu): How Discourses of Nationalism, Education, and Development Have Placed a Large, Indigenous Language at Risk. D.Phil. Dissertation, University of Arizona.

xiv. Pauwels A. (2004). Language maintenance. In A. Devis and C. Elder (Eds.) The handbook of applied linguistics (pp: 719-737). Malden, MA: Blackwell.

xv. Wamalwa, E.W and Oluoch, S.B.J. (2013). Language Endangerment and Language Maintenance: Can Endangered Indigenous Languages of Kenya Be Electronically Preserved? International Journal of Humanities and Social Science, Vol. 3 No. 7; April 2013: 258-266.

xvi. Wanjala, B. W. (2009). Inter-dialect maintenance and shift in the contact of Lubukusu and Lutachoni. MA Thesis, Kenyatta University.

xvii. Weinreich, U. (1953). Languages in contact: Findings and problems. New York: Linguistic Circle. 